\title{
Two new species of Elaphropeza Macquart, 1827 (Diptera, Hybotidae, Tachydromiinae) from Bolivia, Brazil and Peru
}

\author{
Rafael Augusto Pinheiro de FREITAS-SILVA ${ }^{1}$, Rosaly ALE-ROCHA ${ }^{2}$ \\ ABSTRACT \\ Two new species of Elaphropeza Macquart, 1827 are described and illustrated: Elaphropeza atrata sp. nov. (Brazil and Peru) and \\ Elaphropeza longiseta sp. nov. (Bolivia and Brazil). An updated key to Elaphropeza species from Amazon Basin is provided. The \\ number of species of Elaphropeza in the Amazon Basin region is increased to seven with an increase to 36 for the Neotropical \\ Region. \\ KEYWORDS: Empidoidea, Hybotidae, Amazonia, Neotropical region, predacious flies.

\section{Duas espécies novas de Elaphropeza Macquart, 1827 (Diptera, Hybotidae, Tachydromiinae) da Bolívia, Brasil e Peru}

\section{RESUMO}

Duas espécies novas de Elaphropeza Macquart, 1827 são descridas e ilustradas: Elaphropeza atrata sp.nov. (Brasil e Peru) e Elaphropeza longiseta sp. nov. (Bolívia e Brasil). Uma Chave atualizada para as espécies de Elaphropeza da bacia amazônica é fornecida. O número de espécies de Elaphropeza na regiáo da bacia amazônica foi ampliado para sete com o crescimento para 36 na região neotropical.

PALAVRAS-CHAVE: Empidoidea, Hybotidae, Amazonia, região Neotropical, moscas predadoras.

1 Instituto Nacional de Pesquisas da Amazônia - INPA. rfreitas.silva@yahoo.com.br

2 Instituto Nacional de Pesquisas da Amazônia - INPA. alerocha@inpa.gov.br 


\section{INTRODUCTION}

Members of the genus Elaphropeza comprise relatively small predaceous flies and included species can be distinguish from other Tachydromiinae by the following set of characters: occiput convex, gena not developed, two pairs of ocellar setae, eyes with microtrichia, conical to lanceolate postpedicel bearing a distal arista-like stylus, anepisternum bare, wing with shortened basal radial cell (br) and abdominal intersegmental modification present between tergites 3-5 or 4-5 (Shamshev and Grootaert 2007; Cumming and Sinclair 2009).

Despite being a relatively well studied group in the Palaearctic and Oriental regions, the Afrotropical, Australasian and Neotropical faunas remain little studied. The most recent studies in Neotropical Elaphropeza are Rafael (1995) that redescribed E. monochaeta (Bezzi, 1909) from Bolivia, and Freitas-Silva and Ale-Rocha (2009) that redescribed five species from the Amazon Basin and provided a key to species from this region. Prior to this study, Neotropical Elaphropeza were represented by 34 species, including five valid species from the Amazon Basin region (Yang et al. 2007; Freitas-Silva and Ale-Rocha 2009).

\section{MATERIAL AND METHODS}

Material studied was loaned from the following institutions: California Academy of Sciences, San Franscisco (CAS), Invertebrates Collection of Instituto Nacional de Pesquisas da Amazonia, Manaus (INPA), Museu Paraense Emilio Goeldi, Belem (MPEG) and The National History Museum, London (NHM).

Terminology and abbreviations follow McAlpine (1981) for adult structures, except the homologies for male and female terminalia where terms of Cumming et al. (1995), Sinclair (2000) and Sinclair and Cumming (2006) are followed. The term 'bristle' is used for more or less differentiated setae on legs, except the thin and the squamiform setae on tarsi, where the term 'setulae' was used. Acrostichal setae in descriptions reflect the number of rows on each side of the scutum. Terminalia were macerated in hot $85 \%$ lactic acid and stored in a microvial with glycerine. Wings were photographed after removal from the body and mounted between cover slides with Canada balsam. Slides and microvials were attached to each specimen pin.

Costal index is based on measurements taken directly from tip to tip of the first four veins where they reach the costa, with the first section measured from the humeral cross-vein rather than the wing base for the purpose of accuracy (i.e. the distance betweem Sc and $\mathrm{R}_{1}, \mathrm{R}_{1}$ and $\mathrm{R}_{2+3}, \mathrm{R}_{2+3}$ and $\mathrm{R}_{4+5}, \mathrm{R}_{4+5}$ and $\mathrm{M}$ respectively). This index records the proportional length of the four sections of costa, which can vary between species.
Illustrations of male terminalia are based and presented in their unrotated positions.

Information presented between square brackets is complementary data absent from labels.

\section{RESULTS}

\section{Key to species of Elaphropeza Macquart from the Amazon Basin}

This is an adaptation to the key presented in FreitasSilva and Ale-Rocha (2009), added of the two new species introduced by the present paper.

1. Hind tibia with 1 strong anterodorsal bristle ............. 2

- Hind tibia with 2 or more strong anterodorsal bristles ....... 3

2. Predominantly black species. Scutum with few setae, dorsocentral and intra-alar setae distinctly separated. Hind leg black, except basal half of femur yellow

E. monochaeta (Bezzi, 1909)

- Yellow to reddish species. Scutum moderately hairy, dorsocentral and intra-alar setae hardly separated. All legs yellow to reddish yellow ............ E. biseticauda (Smith, 1963)

3. Hind tibia bearing 2 strong anterodorsal bristles ......... 4

- Hind tibia bearing 9-10 strong anterodorsal bristles ........... 6

4. Occiput densely tomentose. Male fore femur with posteroventral spinule-like bristles, mid femur with 2-5 prominent anterior bristles on apical half. Male right cercus with clavate projection arising under membranous area that connects cerci .............................. E. flavida (Williston, 1896)

- Occiput lacking tomentum at least on shining region adjacent to upper part of eye. Male fore femur lacking spinulelike bristles, mid femur lacking prominent anterior bristles (except apicals). Male right cercus without clavate projection 5

5. Postpronotal seta prominent. Vein $\mathrm{R}_{2+3}$ strongly arched, $\mathrm{R}_{4+5}$ remarkably divergent from M. Male cerci separated ..... E. mazaruni (Smith, 1963)

- Postpronotal seta indistinct. Vein $\mathrm{R}_{2+3}$ normally arched, $\mathrm{R}_{4+5}$ parallel to $\mathrm{M}$ near margin. Male cercus completely fused E. similis (Smith, 1963)

6. Scutum black, scutellum brown. Mid and hind femora brown in apical half. Mid femur lacking anterodorsal bristles, hind tibia black bearing 9 strong anterodorsal bristles .....

E. atrata sp. nov.

- Scutum yellow, scutellum yellow with black central marking. Legs entirely yellow. Mid femur with anterodorsal row of long bristles, hind tibia bearing 10 strong anterodorsal bristles E. longiseta sp. nov. 


\section{Elaphropeza atrata sp. nov.}

(Figures 1-4)

Diagnosis. Scutum black, setulose, setae in irregular rows, pronotum, scutellum, meron and postalar callus somewhat paler. Mid and hind femora brown in apical half, hind tibia black, bearing 9 strong anterodorsal bristles with different lengths; hind tarsomere 1 with basal intumescence bearing several very short spinules; wing brown infuscate. Left surstylus with a basal hook-like structure on internal surface.

Etymology: The specific name refers to the dark colored general aspect of the exemplars herein included.

Description. Holotype male: body length, $3.4 \mathrm{~mm}$; wing length, $3.2 \mathrm{~mm}$. Head. Occiput shining black, oral margin brownish yellow. Setation reddish, white pruinescence on lower half and all hind part of occiput, ocellar triangle and a slender stripe on vertex. Frons shining black, tomentose near antennae, with subparallel sides; eyes close but not touching just above antennae; face tomentose. Setae unusually long; two pairs of upwardly directed verticals, inner pair longest, outer pair hardly differentiated from postoculars; ocellars proclinate, anterior pair very long and cruciate, posterior pair about half length of anterior pair, slightly divergent. Antenna yellow, postpedicel and stylus brown. Postpedicel as long as the length of scape and pedicel combined and stylus 5.3 times longer than combined length of scape and pedicel. Palpus dark yellow, ovate, somewhat shorter than brown proboscis.

Thorax shining black, brown on pronotum, scutellum (except basal margin) and meron, dark yellow on postalar callus. Scutum densely setose, setae yellow, relatively long and arranged in irregular rows, conspicuous setae brown; anepisternum lacking tomentum. Scutum somewhat longer than wide, 6 times longer than scutellum. Proepisternum with several short setulae, lacking long setae just above fore coxa; postpronotal seta inconspicuous; 2 notopleural setae (anterior one longest, posterior about two-thirds length of anterior), 3 supra-alar setae (anterior and posterior one long, subequal, mid one about half length of anterior), 1 long postalar seta, basal scutellar seta 3 times shorter than apical. Acrostichals biserial, irregular, extending almost to posterior margin. Dorsocentrals indistinct from intra-alars, apparently with 5 rows, prescutellar dorsocentral about two-thirds length of apical scutellar.

Legs brownish yellow, mid and hind femora brown in apical half, mid tibia brown and hind tibia black, all tarsomeres darkened near apex, tarsomeres 5 dark brown; brownish setation except for some more or less differentiated dark brown setae. Coxae and trochanters with unmodified setation. All femora with subapical bristle more or less distinct, strongest on mid and hind femur. Fore and mid tarsomeres $2-4$ with numerous ventral setulae; empodia large, white. Fore femur somewhat thickened near base. Fore tibia bearing 1 moderately long posteroventral apical bristle. Fore tarsomere 1 with ventral squamiform setulae on distal half. Mid femur slender with numerous rows of ventral spinule-like bristles. Mid tibia bearing several ventral spinules. Mid tarsomere 1 with ventral squamiform setulae on proximal half. Hind femur thickened apically with 8 erect dorsal bristles near base. Hind tibia setulose beneath (especially near apex) bearing 9 strong anterodorsal bristles with different lengths and a short pointed apical tibial projection. Hind tarsus lacking distinct bristles, tarsomere 1 with basal intumescence bearing several very short spinules.

Wing (Figure 4) normally developed, brown infuscate with brown setation; veins dark brown, except base of $\mathrm{R}$ yellow; $\mathrm{C}$ bearing 1 long seta near base, setae on proximal section longer and more spaced than in other sections. Costal index: 33/19/22/07; Rs 1.4 times longer than bm-cu; $\mathrm{R}_{2+3}$ slightly arched reaching $\mathrm{C}$ at middle third of the wing; $\mathrm{R}_{4+5}$ bowed, $\mathrm{M}$ straight, becoming parallel with $\mathrm{R}_{4+5}$ apically; $\mathrm{CuA}{ }_{1}$ reaching wing margin; $A_{1}$ present as a slight fold in membrane. Cell bm 2.3 times longer and twice wider than cell br at their maximum widths; cross-vein bm-cu perpendicular to $\mathrm{CuA}_{1}$; halter pale yellow.

Abdomen dark brown, tergites 3-5 black; tergite 1 membranous; tergites $2-3$ and 5 reduced to subtriangular lateral sclerites, other tergites completely sclerotized; tergite 4 very long; tergite 3 with 2 rows of squamiform setae; tergite 4 with 9 rows; tergite 5 lacking squamiform setae; tergites 3 and 5 with numerous thin setulae; other tergites with unmodified setation. Gland-like structure present between tergites 4-5.

Terminalia (Figure 1) black, large. Cerci divided; left cercus strong bearing several moderately long setae; right cercus slender with some moderately long lateral and 2 long apical setae. Right epandrial lamella (Figure 3) subrectangular, wide with two apical projections, covered partially by short setulae and some long setae. Right surstylus not prominent. Left epandrial lamella partially fused to hypandrium. Left surstylus (Figure 2) subtriangular with short marginal setae, with basal hook-like structure on internal surface (Figure 1). Two rod-shaped apodemes, ventral apodeme longer than ejaculatory apodeme, almost reaching margin of hypandrium. Hypandrium bearing 1 short median seta and another near postgonites. Phallus slender, short.

Female. Unknown.

Variations. Male body length: $3.0-3.4 \mathrm{~mm}$; wing length: 3.4-3.6 mm. One specimen from Peru has scutum, pleuron and legs paler than holotype, with yellow markings on anepisternum and meron.

Type material examined. Holotype male. BRA[ZIL], Rondonia: Nova; Mamore; P[ar]q[ue] Est[adual] de 
Guajara-Mirim; Rio Formoso [white rectangular print label]/ 20-27.x.1995; Armadilha de Luz; J. A. Rafael, A. L. Henriques; LEG [white rectangular print label]/ Holotype male; Elaphropeza atrata sp.nov.; Freitas-Silva \& Ale-Rocha, 2011 [red rectangular print/handwritten [INPA]. Condition of holotype: mounted on minuten pin. Left mid leg glued to a triangle of paper. Left hind leg lost. Abdomen dissected, stored in microvial with glycerin. Right wing between covered glass slides, glued to a piece of hard paper. Triangle, microvial and slides attached to specimen pin.

Paratypes. The same of holotype [1 male, INPA]; BRAZIL, Amazonas: Manaus, Res[erva Florestal] Ducke, Malaise, Ig[arape] Acara, i.viii. 1993, J. Vidal [1 male, INPA]; 1.xi.1993 [1 male, INPA]; Para: Serra Norte, Est[rada] da Serraria, Arm[adilha] Malaise, 10-15.x.1983 [1 male, INPA]; PERU [Huanuco: Leoncio Prado], Tingo Maria, Monson Valley, 23.xii.1954, E. I. Schilinger \& E. S. Ross collectors [1 male, CAS]; 26.x.1954 [2 males, CAS].

Geographical records. Brazil (Amazonas, Para, Rondonia), Peru (Tingo Maria).

\section{Elaphropeza longiseta sp. nov.}

(Figures. 5-11)

Diagnosis. Occiput yellow, brownish yellow on upper third. Scutum very hairy. Scutellum with black central marking. Mid femur with anterodorsal row of long bristles. Hind tibia bearing 1 strong dorsal sub-basal, 1 strong posteroventral subapical and 10 anterodorsal bristles along length. Male terminalia notably large with several very long brown ribbon-like setae arising from right epandrial lamella and right cercus, ventral apodeme exceeding proximal margin of gonocoxal apodeme.

Etymology: The specific name refers to the several long ribbon-like setae located on the right cercus and right epandrial lamella of the male terminalia.

Description. Holotype male (except terminalia): body length, $4.0 \mathrm{~mm}$; wing length, $4.5 \mathrm{~mm}$. Head. Occiput shining yellow, brownish yellow on upper third, yellow pruinescence except on vertex; setation brownish. Frons shining yellow with slightly divergent sides, eyes almost contiguous just

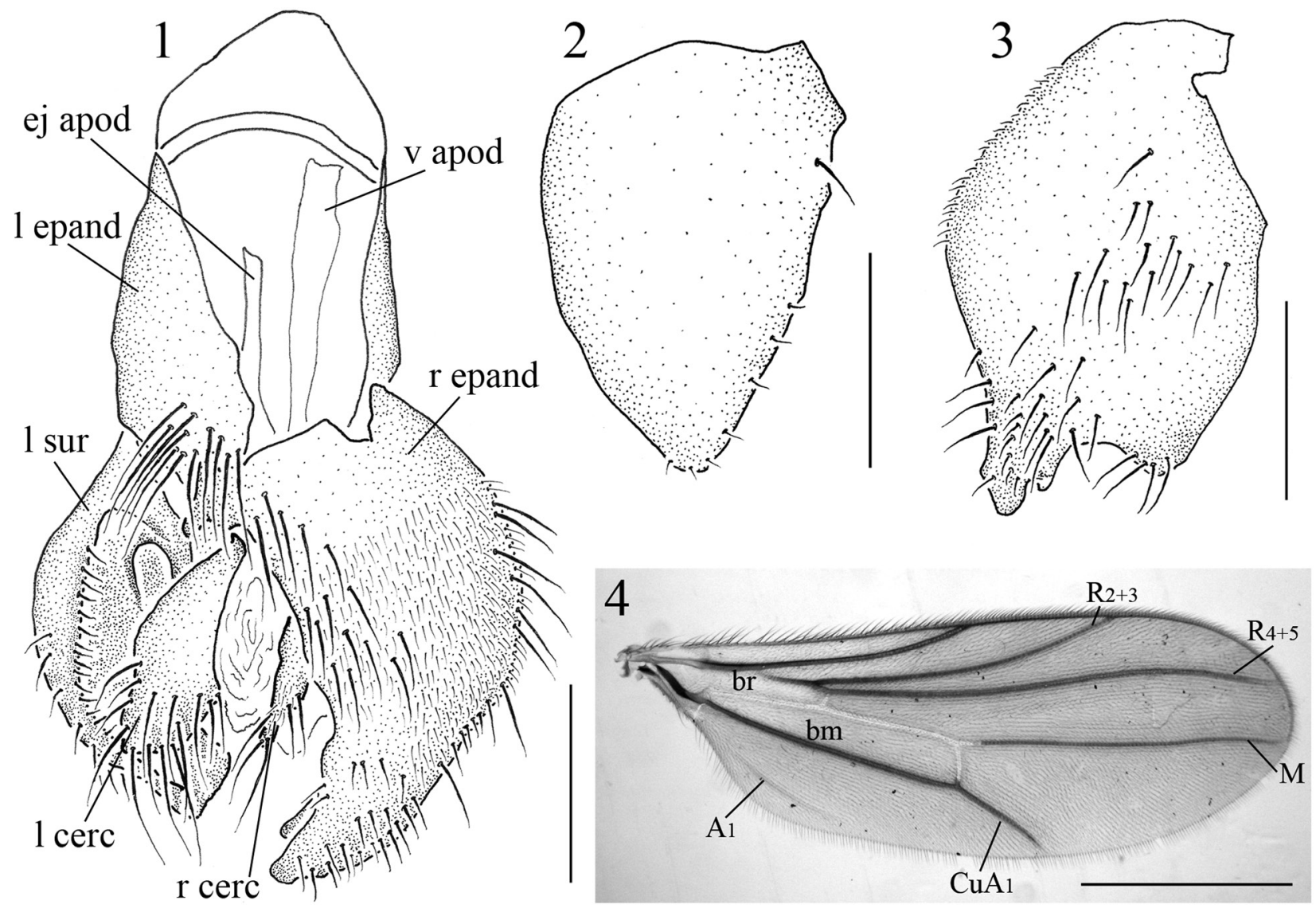

Figures 1-4 - Elaphropeza atrata sp. nov. [holotype]. 1. Epandrium with cerci, dorsal view. 2. Left surstylus, lateral view. 3. Right epandrial lamella, lateral view

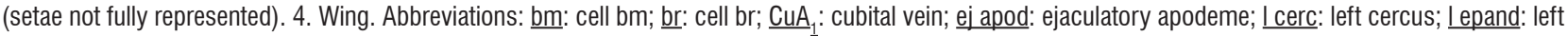

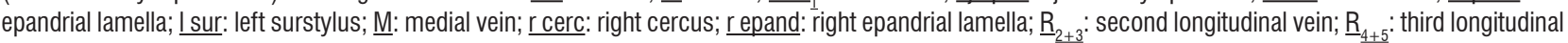

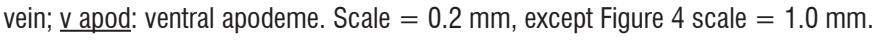


above antennae; face tomentose. Two pairs of upwardly directed verticals, inner and outer pairs long, subequal. Ocellars proclinate, anterior pair long and cruciate; posterior pair minute, divergent. Antenna pale yellow. Postpedicel 1.5 times and stylus 6.7 times longer than combined length of scape and pedicel. Palpus yellow, lanceolate, shorter than the yellow proboscis.

Thorax shining dark yellow with black central marking on scutellum and subscutellum. Scutum densely setose, yellow setation, conspicuous setae brown; anepisternum lacking tomentum. Scutum somewhat longer than wide, 5.7 times longer than scutellum. Proepisternum lacking setae just above fore coxa; postpronotal seta inconspicuous; 2 notopleural setae (anterior one longest, posterior about half length of anterior); 3 supra-alar setae (anterior and posterior one long, subequal, mid one about half length of anterior); 1 long postalar seta; basal scutellar seta 3.5 times shorter than apical. Acrostichals triserial, extending to posterior margin of scutum. Dorsocentrals indistinct from intra-alars, apparently with 6 rows; prescutellar dorsocentral about two-thirds length of apical scutellar.

Legs entirely yellow with all tarsomeres 5 brown with long dorsal setae; setation yellow except for some more or less differenciated brownish setae. Coxae and trochanters with unmodified setation. All femora with subapical bristle more or less distinct, strongest on mid and hind femur. Fore and mid tarsomeres 2-5 with numerous ventral setulae. Fore and mid femora somewhat thickened near base. Fore tibia bearing

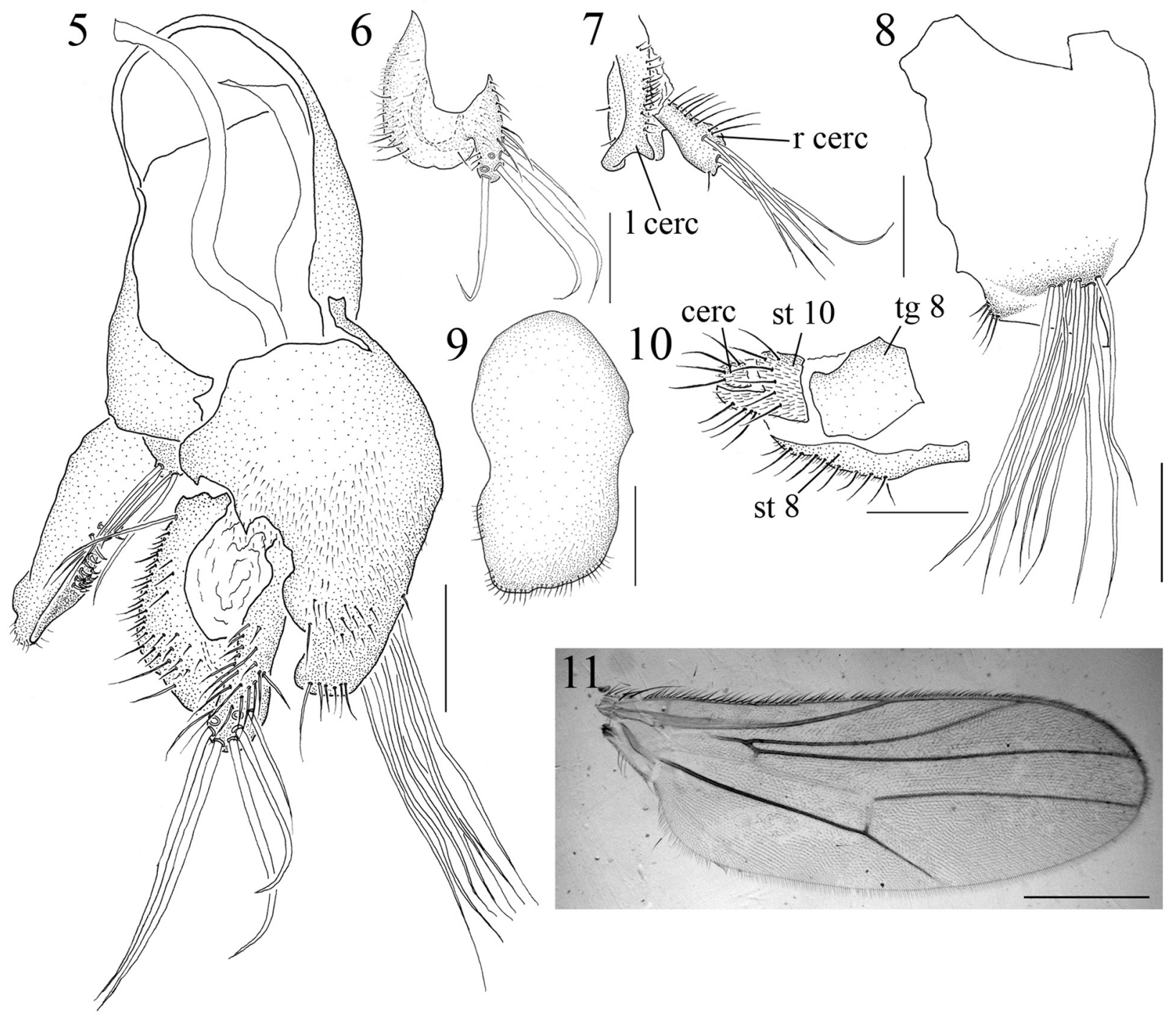

Figures 5-11 - Elaphropeza longiseta sp. nov. [male from Rurrenabaque, female from Balawau]. 5. Epandrium with cerci, dorsal view. 6. Cerci, dorsal view. 7. Cerci, lateral view. 8. Right epandrial lamella, lateral view. 9. Left surstylus, lateral view. 10. Ovipositor, lateral view. 11. Wing. Abbreviations: cerc: cercus; 1

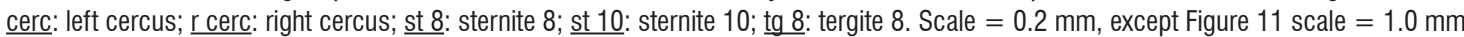


1 long posteroventral apical bristle. Fore tarsus with several antero- and posteroventral bristles longer than others, fore tarsomere 1 with ventral dark yellow squamiform setulae on distal half. Mid femur with numerous rows of ventral spinulelike bristles and anterodorsal row of long bristles (longest near base of femur). Mid tibia with sub-basal, moderately long, dorsal bristle, numerous short ventral spinule-like bristles and 1 upcurved apical spinule. Mid tarsomeres 1-4 with long ventral apical bristles, strongest on tarsomere 1 . Hind femur with about 14 erect dorsal bristles near base. Hind tibia somewhat thickened apically with a short pointed apical tibial projection, bearing 1 strong dorsal sub-basal, 1 strong posteroventral subapical and 10 other anterodorsal bristles along length. Hind tarsomere 1 with several strong bristles longer than others, 1 anteroventral very long.

Wing (Figure 11) normally developed, hyaline; veins dark yellow with brown setation; $\mathrm{C}$ bearing 1 long seta near base, setae on proximal section longer and more spaced than in other sections. Costal index: 36/22/20/07; Rs as long as bm-cu; $\mathrm{R}_{2+3}$ slightly arched, sinuous near apex, reaching $\mathrm{C}$ at apical third of the wing; $\mathrm{R}_{4+5}$ and $\mathrm{M}$ somewhat curved, slightly divergent distally; $\mathrm{CuA}_{1}$ evanescent apically but reaching wing margin; $\mathrm{A}_{1}$ present as a slight fold in membrane. Cell bm 2.5 times longer and 1.5 times wider than cell br; cross-vein bm-cu perpendicular to $\mathrm{CuA}_{1}$; halter pale yellow.

Abdomen with tergite 1 pale yellow, membranous; tergites 2-3 reduced to subtriangular lateral sclerites, other tergites completely sclerotized; tergites 2-3 and 6-7 dark yellow; tergite 4 dark brown with about 10 rows of squamiform setae; tergite 5 brownish yellow lacking squamiform setae, bearing numerous short lateral setae; other tergites with unmodified setation. Gland-like structure present between tergites 4-5.

Terminalia (paratype from Rurrenabaque) (Figure 5) brownish yellow, notably large. Cerci (Figures 6-7) completely fused together; left cercus (Figure 6) arc-like in dorsal view bearing several short lateral setae, with ventral receptacle-like projection (Figure 7); right cercus (Figures 5-7) club-like with several short setae and 6 very long ribbon-like apical setae. Right epandrial lamella (Figure 8) subrectangular, wide, with an apical projection and several very long ribbon-like setae arising from a short callus. Right surstylus not prominent. Left epandrial lamella partially fused to hypandrium. Left surstylus (Figure 9) subrectangular, elongate, with several short setae on distal half (not fully represented in figure 5) and 9 short strong setae on internal suface (Figure 5). Two rod-shaped apodemes, ventral apodeme longer than ejaculatory apodeme, exceeding margin of hypandrium. Hypandrium bearing 1 short median seta and another near postgonites. Phallus slender, short.

Female. Body length: $3.6 \mathrm{~mm}$; wing length: $4.2 \mathrm{~mm}$. Tergites 3 and 5 lacking squamiform setae. Ovipositor (Figure
10, specimen from Balawau) with tergite 8 short, separated from the slender sternite, pointed apically, not folded; sternite 10 as in figure. Cercus yellow. Otherwise similar to male.

Type material examined. Holotype male. [BOLIVIA: El Beni, Puerto] Rurrenabaque; 18.vii..[19]19 [No collector ] [white rectangular handwritten label] /Holotype male; Elaphropeza; longiseta sp. nov.; Freitas-Silva \& Ale-Rocha 2011. [red rectangular print/handwritten label]. Condition of holotype: in good condition, mounted on minuten pin. Abdomen in microvial with glycerine, attached to specimen pin [NHM].

Paratypes. The same of holotype, Paratype male, Elaphropeza longiseta sp.nov. Freitas-Silva \& Ale-Rocha, 2011 [1 male, INPA]; [BRAZIL, Amazonas: Barcelos] Balawau [on the label Balalaw-u] [1 $\left.{ }^{\circ} 48^{\prime} 08^{\prime \prime N} 63^{\circ} 47^{\prime} 33^{\prime \prime} \mathrm{W}\right]$, Malaise-Terra, 17-19.v.1995, [Maria] Fernanda [Souza Fernandez], Luiz [Aquino], Paratype female [1 female, INPA].

Geographical records. Bolivia (Rurrenabaque), Brazil (Barcelos).

\section{DISCUSSION}

The two new species can be distinguished from other Elaphropeza mainly by their size and hind tibia armed with several strong anterodorsal bristles. Also, in E. longiseta sp. nov., the several ribbon-like setae on the right cercus and right epandrial lamella allows this species to be easily recognized even without dissection. Furthermore, the setulose scutum with setae arranged in irregular rows and the color pattern of scutum and legs are good characteristics to identify $E$. atrata sp. nov. The similar species, E. inermis (Melander, 1918) from Central America is smaller in size (about 2.3 $\mathrm{mm}$ ), has the antenna entirely brown, pronotum black, tibiae dark brown, and although agreeing with $E$. atrata sp. nov. in having the postalar callus dark yellow, has the hind tibia with only one strong anterodorsal bristle. The Neotropical species Elaphropeza comata (Melander 1918) is much smaller (about $2.0 \mathrm{~mm}$ ) and despite bearing several anterodorsal bristles on the hind tibia, it is yellow and the first hind tarsomere has seven erect dorsal setae (Freitas-Silva and Ale-Rocha in preparation).

The mating position in Hybotidae is still poorly known, but Huber et al. (2007) suggest based in photographs of pairs in copula that species assume the position false-male-above, "where the male sits above the female but bends his abdomen sideways around her so that his genitalia contact the female from below". The presence of several ribbon-like setae on the male terminalia of $E$. longiseta sp. nov. is a interesting feature, because it seems to be unique in the genus. It is probable that these setae are involved in some species-specific stimulatory mechanism, but there is no corresponding morphological 
structure on the female ovipositor that can be linked or associated.

It is not the first time the presence of ribbon-like setae on the male terminalia has been related to a possible stimulatory function in insects. For example, Eberhard (2004) reported a male of Aelurus septentrionalis (Hymenoptera, Tiphiidae) with several long ribbon-like setae on the apical portion of the paramere, which appear splayed on the sides of the female's gaster during copulation. Eberhard (2004) did not find any corresponding modification on the female gaster near the placement of the male setae and suggested an apparent stimulatory function for these setae.

Finally, the number of species of Elaphropeza in Amazon Basin region has now been increased to seven with an increase to 36 for the entire Neotropical Region.

\section{ACKNOWLEDGEMENTS}

We are grateful to the following curators for sending us the specimens used on this study: Dr. Augusto Loureiro Henriques (INPA); Dr. Charles Griswold (CAS); Dr. Orlando Tobias Silveira (MPEG); Dr. Erica McAlister (NHM), also for sending us information about the holotype of the species E. longiseta sp. nov.; Dr. Maria Fernanda Souza Fernandez (UEA), Dr. Márcio Luis Leitão Barbosa (INPA) and Luiz Aquino for elucidating some doubts about the details of the locality of one exemplar of $E$. longiseta sp. nov.. We are also grateful to the Brazilian government through the Conselho Nacional de Desenvolvimento Científico e Tecnológico $(\mathrm{CNPq})$ for fellowships to both authors and financial support ("Sistemática de Hybotidae (Diptera, Empidoidea) da região Neotropical” - Edital MCT/CNPq 15/2007 - Universal). We thank also the very useful suggestions made by the two anonymous referees.

\section{REFERENCES}

Cumming, J.M; Sinclair, B.J.; Wood, D.M. 1995. Homology and phylogenetic implications of male genitalia in DipteraEremoneura. Entomologica scandinavica, 26: 121-151.
Cumming, J.M.; Sinclair, B.J. 2009. 48. Empididae (dance flies, balloon flies, predaceous flies), p. 653-670. In. Brown, B.V; Borkent, A.; Cumming, J.M.; Wood, D. M.; Woodley, N.E.; Zumbado, M.A. (Eds.). Manual of Central American Diptera. Vol. 1. NRC Research Press, Ottawa, Ontario.

Eberhard, W.G. 2004. Apparent stimulatory function of species-specific male genitalic setae in Aelurus septentrionalis (Hymenoptera: Tiphiidae). Journal of the Kansas Entomological Society, 77 (4): 837-839.

Freitas-Silva, R.A.P.; Ale-Rocha, R. 2009. Revision of the species of Elaphropeza Macquart, 1827 (Diptera: Hybotidae, Tachydromiinae) from Amazon Basin region and some remarks about E. ciliatocosta (Bezzi, 1904). Zootaxa, 2245: 32-46.

Huber, B.A.; Sinclair, B.J.; Schmitt, M. 2007. The evolution of asymmetric genitalia in spiders and insects. Biological Reviews, 82: 647-698.

McAlpine, J.F. 1981. Morphology and terminology-adults, p. 9-64. In. McAlpine, J.F.; Peterson, B.V.; Shewell, G.E.; Teskey, H.J.; Vockeroth, J.R.; Wood, D.M. (Eds.). Manual of Neartic Diptera. Vol. 1. Agriculture Canada Monograph, Ottawa, Ontario.

Rafael, J. A. 1995. Revision of Mario Bezzi's Neotropical species of Empididae. II. Tachydromiinae. Revista Brasileira de Entomologia, 39 (4), 733-739 (In Portuguese, with abstract in English).

Shamshev, I.V.; Grootaert, P. 2007. Revision of the genus Elaphropeza Macquart, 1827 (Diptera: Hybotidae) from the Oriental region, with a special attention to the fauna of Singapore. Zootaxa, 1488: 1-164.

Sinclair, B.J. 2000. Chapter 1.2. Morphology and terminology of Diptera male terminalia, p. 53-74. In. Papp, L.; Darvas, B. (Eds.). Contributions to a Manual of Palaeartic Diptera. Vol. 1. Science Herald, Budapest.

Sinclair, B.J.; Cumming, J.M. 2006. The morphology, higher-level phylogeny and classification of the Empidoidea (Diptera). Zootaxa, 1180: 1-172.

Yang D.; Zhang, K.; Yao, G.; Zhang, J. 2007. World catalog of Empidoidea (Insecta: Diptera). China Agricultural University Press, Beijing, China. 599 pp.

Recebido em 03/05/2010

Aceito em 03/08/2010 
